\title{
Nitrification Potential of Achromobacter xylosoxidans Isolated from Fresh Water Finfish Farms of Kerala, India
}

\author{
K. Ahamed Basha*, Toms C. Joseph ${ }^{1}$, K.V. Lalitha ${ }^{1}$, D. Vineetha ${ }^{1}$, G. Rathore ${ }^{2}$, \\ Gayatri Tripati ${ }^{3}$ and K. Pani Prasad ${ }^{3}$ \\ ${ }^{1}$ ICAR-Central Institute of Fisheries Technology, Cochin, Kerala -682 029, India \\ ${ }^{2}$ ICAR-National Bureau of Fish Genetic Resources-Lucknow-226 002, India \\ ${ }^{3}$ ICAR-Central Institute of Fisheries Education, Versova, Mumbai-400061, India \\ *Corresponding author
}

\begin{tabular}{|l|}
\hline Key w or d s \\
Sediment, PCR, \\
16SrDNA, \\
Achromobacter \\
xylosoxidans, \\
sodium pyruvate, \\
Hetertrophic \\
nitrification
\end{tabular}

A heterotrophic strain ACM-1, isolated from Pangasius spp fish farms showed an ability to convert ammonium to nitrate under aerobic conditions. Based on the molecular phylogenetic analysis 16S rRNA gene sequence ACM-1 matched similarity to Achromobacter xylosoxidans (100\%). ACM-1 showed amplification for Betaproteobacterial 16S AOB gene $(465 \mathrm{bp})$ confirming the characteristic feature of ammonia oxidation. Sodium pyruvate $(1 \%)$ was confirmed as the probable carbon source for the luxurious growth of Achromobacter xylosoxidans among the six carbon sources tested. At $30^{\circ} \mathrm{C}, 5 \%$ preculture and $120 \mathrm{rpm}$ in shaker, ACM-1 could able to remove $100 \%$ ammonium within $36 \mathrm{~h}$. The ammonium removal rate was reported to be $1.3 \mathrm{NH}_{4}^{+}-\mathrm{N} \mathrm{mg}$ $\mathrm{L}^{-1} \mathrm{~h}^{-1}$ at $30^{\circ} \mathrm{C}$. The rate of ammonium removal at different temperature $\left(20^{\circ} \mathrm{C}, 25^{\circ} \mathrm{C}, 37^{\circ} \mathrm{C}\right)$ ranged between 0.9 to $1.33 \mathrm{NH}_{4}^{+}-\mathrm{N} \mathrm{mg} \mathrm{L}^{-1} \mathrm{~h}^{-1}$. The nitrite produced during this experiment remained at constant rate and nitrate concentration increased after the initial hours of experiment. Therefore, the results demonstrate that Achromobacter xylosoxidans ACM-1 can remove ammonium in batch cultures and could be applied in aquaculture farms as a biological nitrifier.

\section{Introduction}

Over the decades, Aquaculture as a traditional practice has evolved to science based activity to meet the demands of food security as well as national economy. During 2016, world aquaculture production has projected to 73.8 mt with US $\$ 160.2$ billion as an estimated first-sale value (FA0.2016). Total world aquaculture production accounted for $44.1 \%$ during 2014 and $31.1 \%$ as compared in 2004 .
Feed is a crucial input for Semi -intensive and intensive aquaculture and usually contributes over $40-50 \%$ production costs but nearly $36 \%$ of the feed is excreted in the form of organic waste (Brune et al., 2003). The protein requirement of fish is about two to three times higher than that of mammals. Ammonium is one of the end products of protein metabolism (Walsh and Wright, 1995). In water, ammonia occurs in two forms which together are called total ammonia 
nitrogen, or TAN. Chemically, these two forms are ionized ammonia $\left(\mathrm{NH}_{4}{ }^{+}\right)$, unionized ammonia $\left(\mathrm{NH}_{3}\right)$. Haywood (1983) observed that unionized ammonia is $300-400$ times more toxic than ionized ammonium. The unionized ammonia is more toxic than ionized ammonia because it is lipid soluble and consequently traverses biological membranes more readily than the charged and hydrated $\mathrm{NH}^{4+}$ ions (Korner et al., 2001). The proportion of TAN that exists in the toxic form varies with increasing water, $\mathrm{pH}$ and temperature. Driving sources of ammonia nitrogen into the earthen ponds are mainly through inputs such as inorganic fertilizers such as urea, mineralization of fish waste and organic matter decomposition (Boyd, 2001). In intensive as well as Semi-intensive aquaculture systems, about 20-40\% of nitrogen in feed are utilized and the remaining percentage of nitrogen can be regarded as inflow in to the pond sediment followed by mineralization (Folke and Kautsky, 1989). The lethal and sub-lethal effects of unionized ammonia in sensitive fish are such as gill damage, blood oxygen-carrying capacity reduction, lack and depletion of adenosine triphosphate (ATP) in the brain, and the liver and kidneys malfunction (Arillo et al., 1981;Camargo and Alonso 2006; Lang et al., 1987; Russo 1985; Tomasso et al., 1980). The 96-hr $\mathrm{LC}_{50}$ of ammonia for rainbow trout is between 0.32 to $0.93 \mathrm{mg} \mathrm{L}^{-1}$; cutthroat trout, $0.50-0.80 \mathrm{mg} \mathrm{L}^{-1}$; freshwater prawns, 2.00$2.50 \mathrm{mg} \mathrm{L}^{-1}$; school prawns, $1.39 \mathrm{mg} \mathrm{L}^{-1}$; southern white shrimp, 0.69-1.20 $\mathrm{mg} \mathrm{L}^{-1}$; pacific white shrimp, 1.20-2.95 $\mathrm{mg} \mathrm{L}^{-1}$ (Boyd, C.E., 2013). In most cases, the acceptable level of unionized ammonia in aquaculture systems is $0.025 \mathrm{mg} \mathrm{L}^{-1}$ (Chen et al., 2006). Biological removal of ammonia in earthern ponds takes place by several processes includes algal assimilation, bio-filtration, biofloc technology and nitrification (Hargreaves, 1998). Nitrification is a major process in the nitrogen $(\mathrm{N})$ cycling, including a two step process, the oxidation of ammonia to nitrite and subsequently nitrite to nitrate (Prosser, 1989). Ammonia-oxidizing bacteria (AOB) are obligate chemolithoautotrophs, they use ammonia for respiration as well as for cell synthesis and carbon dioxide as the only carbon source (Chain et al., 2003). Autrotrophic AOB are exceedingly slow growing with doubling time of 7-8 $\mathrm{h}$ under ideal conditions (Watson, 1971), more than $26 \mathrm{~h}$ for nitrite bacteria and $60 \mathrm{~h}$ for nitrate bacteria (Shilo and Rimon, 1982) under insitu conditions making their isolation difficult, time-consuming. Interestingly heterotrophic nitrifiers such as Rhodococcus spp (Chen et al., 2012), Alcaligenes faecalis (Joo et al., 2005), Bacillus spp. LY (Zhao et al., 2010a) Bacillus methylotrophicus (Zhang et al., 2012), Psuedomonas stutzeri (Zhang et al, 2011) Acinetobacter calcoaceticus (Zhao et al., 2010) were reported widely under various environments. Therefore, an attempt was made to isolate, characterize the ammonia oxidizing bacteria from aquaculture farms and to estimate their ammonia oxidation rates at various temperatures.

\section{Materials and Methods}

Sediment samples were collected randomly from four Pangasius spp fish farms at four corners and centre, maintained in ice and transported with in $4 \mathrm{~h}$ to the laboratory. The fish ponds varied in size from 0.2-0.5 ha with a stocking density of 8000-12000 fingerlings/ ha.

All the four fish farms were fed with chicken poultry waste as a supplementary diet at the rate of 3-4 \%body weight without any aeration facilities. From each farm, sediment samples were mixed and subsamples in triplicate were taken for analysis of ammonium, nitrate, dry weight, total carbon, $\mathrm{pH}$ and isolation of ammonia oxidizing bacteria (AOB). 


\section{Determination of physico-chemical analysis}

Sediment samples were processed for the estimation of mineral nitrogen (ammonium, nitrite, nitrate) following calorimetric method (Bollmann et al., 2011; Kandeler and Gerber 1988; Keeney DR, Nelson DW, 1982; Shand et al., 2008). Initially, 3-4 g sediment samples were mixed with $2 \mathrm{M} \mathrm{KCl}$ in the ratio $1: 10$, and were kept in shaking condition for $1 \mathrm{~h}$ at $200 \mathrm{rpm}$, centrifuged at $7500 \mathrm{~g}$ for $10 \mathrm{~min}$. The supernatant was used for mineral nitrogen analysis. All the sediment samples were kept for drying for $24 \mathrm{~h}$ at $110^{\circ} \mathrm{C}$ to determine the dry weight. Organic carbon was determined using Walkley and Black method (1934). pH was estimated by suspending sediment in water (1:2.5 ratios) using $\mathrm{pH}$ meter.

\section{Isolation and characterization of AOB from sediment}

Ten grams of sediment was enriched in the $100 \mathrm{ml}$ mineral salt media (Verhagen and Laanbroek, 1991) containing $\left(\mathrm{NH}_{4}\right)_{2} \mathrm{SO}_{4} 3.3 \mathrm{~g}$ $\mathrm{L}^{-1}, \mathrm{NaCl}, 0.585 \mathrm{~g} \mathrm{~L}^{-1}, \mathrm{KH}_{2} \mathrm{PO}_{4} 0.054 \mathrm{~g} \mathrm{~L}^{-1}$, $\mathrm{KCl} 0.075 \mathrm{~g} \mathrm{~L}^{-1}, \mathrm{CaCl}_{2} .2 \mathrm{H}_{2} \mathrm{O} 0.147 \mathrm{~g} \mathrm{~L}^{-1}$, $\mathrm{MgSO}_{4} .7 \mathrm{H}_{2} \mathrm{O}, 0.049 \mathrm{~g} \mathrm{~L} \mathrm{~L}^{-1}$, trace elements solution $1 \mathrm{ml} \mathrm{L}^{-1}$ (Verhagen and Laanbroek, 1991), 0.04\% Bromothymol blue solution, 5 $\mathrm{ml} \mathrm{L}{ }^{-1}$. HEPES buffer as a buffering agent was added to the media four times to the final ammonium concentration. The final $\mathrm{pH}$ of the media was adjusted to 7.8. The flasks were incubated in dark condition at $25{ }^{\mathrm{O}} \mathrm{C}$ for $10-15$ days and samples were monitored for every 4 days for reduction in $\mathrm{pH}$ as well as color change of MSM media from blue to red. Cultures that consumed around $80 \%$ or more of the $\mathrm{NH}^{4+}$ were transferred into fresh medium at weekly intervals for 5 weeks. One $\mathrm{ml}$ of young culture was serially diluted to $10^{2}-10^{6}$ in mineral salt medium with $10 \mathrm{mM}$ $\mathrm{NH}_{4}{ }^{+}$and $1 \mathrm{ml}$ diluted cultures were transferred to $100 \mathrm{ml}$ of MSM media with $2 \%$ agar using pour plate method. Plates were sealed with parafilm and incubated for 3-4 months at $30 \pm 2^{\circ} \mathrm{C}$. Representative colonies were picked, transferred into the MSM broth with $10 \mathrm{mM}$ of ammonium and incubated under shaking condition for 1-2 weeks. Positive cultures showing oxidation of ammonium were purified onto the MSM media with $2 \%$ agar and purified colonies were transferred on to the Trypticase soya agar slants. Biochemical identification of isolates was performed as suggested by the Bergey's Manual of Systematic Bacteriology (Garrity et al., 2004).

\section{Betaproteobacterial AOB amplification using PCR}

Bacterial DNA as a template for 16SrRNA and AOB amplification was isolated by boiling method. Young culture (18-20 h) was centrifuged at $10,000 \mathrm{rpm}$ for $10 \mathrm{~min}$, supernatant was discarded and the pellet was resuspended in $500 \mu \mathrm{l}$ sterile molecular grade water. The whole mixture was centrifuged at $10,000 \mathrm{rpm}$ for $10 \mathrm{~min}$, supernatant was discarded and pellet was resuspended with $200 \mu 1$ molecular grade water. The mixture was subjected to boiling at $95^{\circ} \mathrm{C}$ in a water bath for $10 \mathrm{~min}$, later cooled at $-20^{\circ} \mathrm{C}$ for 10 mins. The mixture was centrifuged at 8,000 rpm for $1 \mathrm{~min}$ and aliquots of $2 \mu \mathrm{l}$ of template DNA were used for PCR. For screening of AOB, PCR amplification was performed employing to CTO-189F and CTO-654R primers. The PCR protocol was followed as described by (Kowalchuk et al., 1997) and PCR products were visualized using $2 \%$ agarose.

\section{Nitrification activity of the isolates using batch culture assay}

To observe the effects of isolates on ammonia removal, $100 \mathrm{ml}$ of MSM media with $50 \mathrm{mg}$ $\mathrm{L}^{-1}$ of ammonium was prepared in $250 \mathrm{ml}$ 
conical flask and autoclaved. For estimation of the microbial growth, $5 \%$ of culture was grown on MSM media (pH-7) with addition of $1 \%$ sucrose, glucose, lactose, sodium acetate, trisodium citrate, sodium pyruvate at $30^{\circ} \mathrm{C}$ for 4 days under shaking conditions. For nitrification studies, the medium was then incubated aerobically with constant speed of $120 \mathrm{rpm}$ at four different temperatures of $20^{\circ} \mathrm{C}, 25^{\circ} \mathrm{C}, 30^{\circ} \mathrm{C}, 37^{\circ} \mathrm{C}$ for approximately 4 days. A $2 \mathrm{ml}$ of aliquots were periodically were examined for determination of ammonium, nitrite and nitrate. A control without culture was used during the experiment period.

\section{Analytical methods}

The O.D of the culture was estimated using UV-Spectrophotometer at $600 \mathrm{~nm}$. In addition, samples were centrifuged at $8000 \mathrm{rpm}$ for 10 min at $4^{0} \mathrm{C}$, further supernatants were filtered using $0.22 \mu$ filter and filtrates were used for chemical analysis. The ammonium concentration was measured at $660 \mathrm{~nm}$ using indophenols blue method (Kandeler and Gerber 1988) whereas nitrite and nitrate assay was carried using calorimetric method at 540nm (Keeney and Nelson 1982); (Shand et al., 2008). For estimation of ammonium (0.1 to $10 \mathrm{ppm})$, nitrite (0.1 to $1 \mathrm{ppm})$ and nitrate (0.1 to $10 \mathrm{ppm})$ a standard curve is plotted, intercept and slope are recorded.

\section{Molecular identification of isolate using 16SrDNA sequencing}

The most promising AOB isolate showing potential nitrification rate was identified by 16SrDNA gene sequencing. Bacterial 16SrDNA amplified using universal bacterial primer $\quad 8 \mathrm{~F} \quad$ (5'-AGAGTTTGATCCT GGCTCAG-3') and 1492R (5'-AAGTCGTA ACAAGGTAACC-3') (Turner et al., 1999). Bacterial 16SrRNA amplification was carried out using universal primers $8 \mathrm{~F}$ and $1492 \mathrm{R}$ primers. The PCR conditions were initial denaturation at $95^{\circ} \mathrm{C}$ for 3 mins and 30 cycles of $95^{\circ} \mathrm{C}$ for $2 \mathrm{~min}, 52^{\circ} \mathrm{C}$ for $1 \mathrm{~min}, 68^{\circ} \mathrm{C}$ for $1.30 \mathrm{~min}$ and final extension at $68^{\circ} \mathrm{C}$ for 7 min. The amplified products (approx 1500bp) were purified and sequenced on automated ABI Sequencer. The 16SrDNA sequence was compared with other bacteria by using BLASTn (https://blast.ncbi. nlm. nih.gov/blast). 16SrDNA reference sequences obtained from Genebank database was aligned using multiple sequence alignment software CLUSTAL $X$ and sequence similarities were determined. A phylogenetic tree was constructed using Mega 7.0.

\section{Statistical analysis}

All the data during this experiment were analysed using Microsoft excel. The Nitrification ratio was calculated as $\left(\mathrm{C}_{\mathrm{O}^{-}}\right.$ $\left.\mathrm{C}_{\mathrm{n}}\right) / \mathrm{h} . \mathrm{C}_{\mathrm{O}}$ is initial concentration of mineral nitrogen compounds. $\mathrm{C}_{\mathrm{n}}$ is final concentration of mineral nitrogen compounds. Time of ACM-1 during the treatment is noted as $h$.

\section{Results and Discussion}

The Physico-chemical parameters of the four farm sediments were mentioned in table 1 . The temperature of the farms ranged from $28.3{ }^{\circ} \mathrm{C}$ to $30.4{ }^{\circ} \mathrm{C}$, sediment $\mathrm{pH}$ 6.7-7.1, salinity $0.1-0.14 \mathrm{ppt}$, organic carbon 0.94 1.07 , and ammonium from 64.0-117.5 $(\mu \mathrm{g}$ $\left.\mathrm{g}^{-1}\right)$, nitrate from $4.70-11.70\left(\mu \mathrm{g} \mathrm{g}^{-1}\right)$.

\section{Isolation and identification of $\mathrm{AOB}$ from fish farms}

A total of 112 bacterial isolates (28 isolates per farm) were picked from the four farms. Among them, 12 isolates were found to be utilizing ammonium within 5 days time interval. All the 12 isolates were gram negative, short rod, motile, oxidase, catalase positive and indole and urease negative. 
Table.1 Physico-chemical parameters of four fish farm sediments

\begin{tabular}{|l|l|l|l|l|l|l|}
\hline Farm & $\begin{array}{l}\text { Temperature } \\
\left({ }^{\circ} \mathrm{C}\right)\end{array}$ & $\mathrm{pH}$ & $\begin{array}{l}\text { Salinity } \\
(\mathrm{ppt})\end{array}$ & $\begin{array}{l}\mathrm{NH}_{4}{ }^{+} \\
(\mu \mathrm{g} / \mathrm{gm}) \mathrm{d} . \mathrm{wt}\end{array}$ & $\begin{array}{l}\mathrm{No}_{3}{ }^{-} \\
(\mu \mathrm{g} / \mathrm{gm}) \mathrm{d} . \mathrm{wt}\end{array}$ & Organic carbon \\
\hline $\mathbf{1}$ & $30.4 \pm 0.20$ & $6.96 \pm 0.11$ & $0.1 \pm 0.03$ & $66.8 \pm 2.95$ & $4.70 \pm 0.82$ & $0.83 \pm 0.045$ \\
\hline $\mathbf{2}$ & $28.3 \pm 0.41$ & $6.89 \pm 0.07$ & $0.1 \pm 0.05$ & $117.5 \pm 5.63$ & $11.7 \pm 1.71$ & $0.94 \pm 0.06$ \\
\hline $\mathbf{3}$ & $29.3 \pm 0.26$ & $6.76 \pm 0.15$ & $0.1 \pm 0.02$ & $64.0 \pm 3.97$ & $6.73 \pm 0.26$ & $1.07 \pm 0.110$ \\
\hline $\mathbf{4}$ & $29.5 \pm 0.5$ & $7.16 \pm 0.03$ & $0.2 \pm 0.03$ & $72.6 \pm 1.35$ & $5.43 \pm 0.39$ & $0.95 \pm 0.105$ \\
\hline
\end{tabular}

Fig.1 A 465 bp product targeting AOB specific Bacterial 16S rRNA detected in ACM-1 A: negative control, B: Positive isolate, C: Test isolate 1; D: Test isolate 2; L: Ladder (100bp)

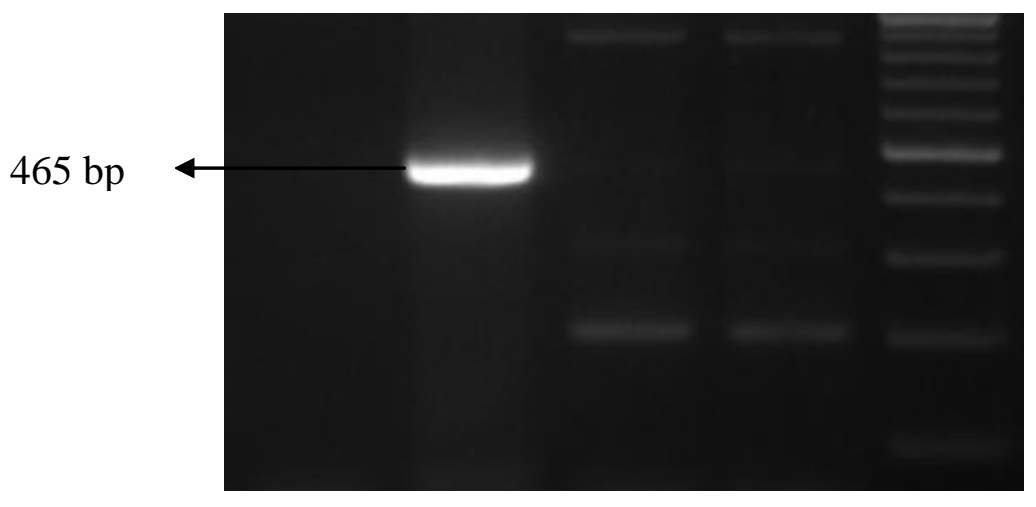

Fig.2 Phylogenetic tree based on the 16S rDNA sequence of strain ACM-1(4 8F 12281-5) with closely related sequences. The numbers at the forks indicate the bootstrap values in percentage

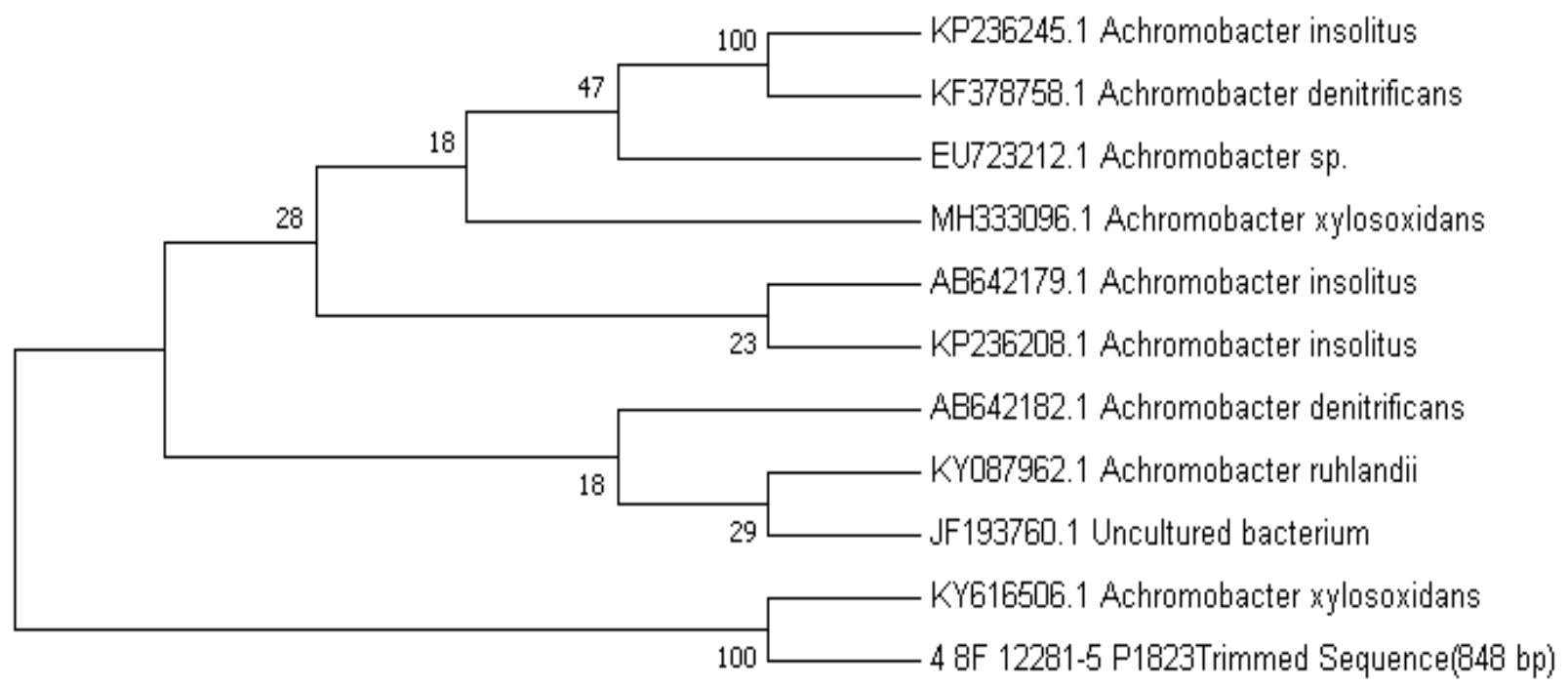


Fig.3 Cell growth and removal of ammonium by ACM-1in MSM containing system at $30^{\circ} \mathrm{C}$.

Symbols: diamonds, $\mathrm{NH}_{4}{ }^{+}-\mathrm{N}$; Squares, cell growth at $\mathrm{OD} 600$

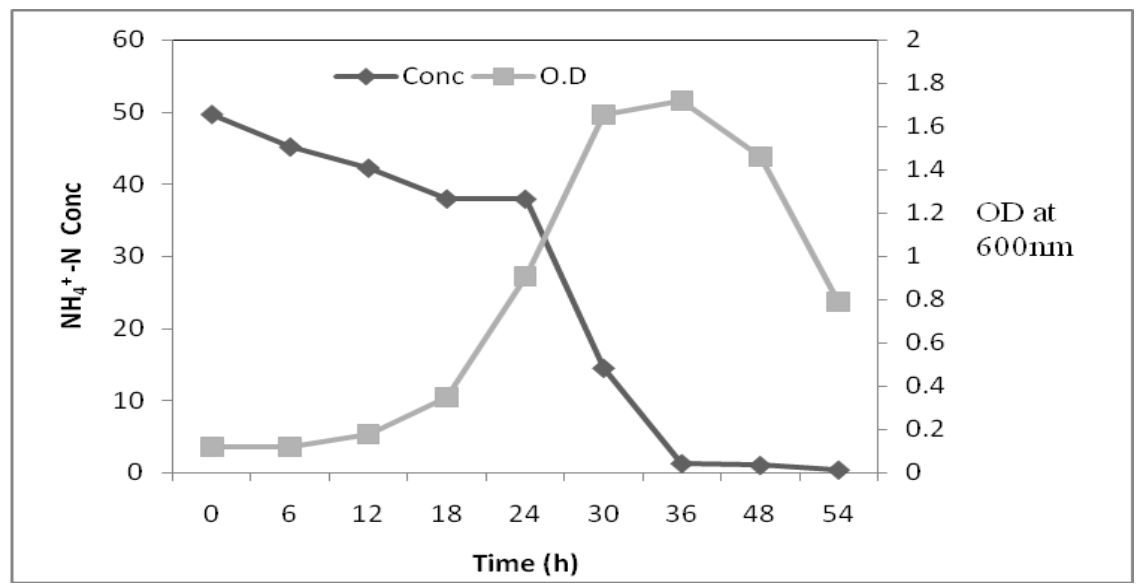

Fig.4 Cell growth and accumulation of Nitrite by ACM-1in MSM containing system $30^{\circ} \mathrm{C}$.

Symbols: diamonds, $\mathrm{No}_{2}{ }^{-}-\mathrm{N}$; Squares, cell growth at $\mathrm{OD}_{600}$

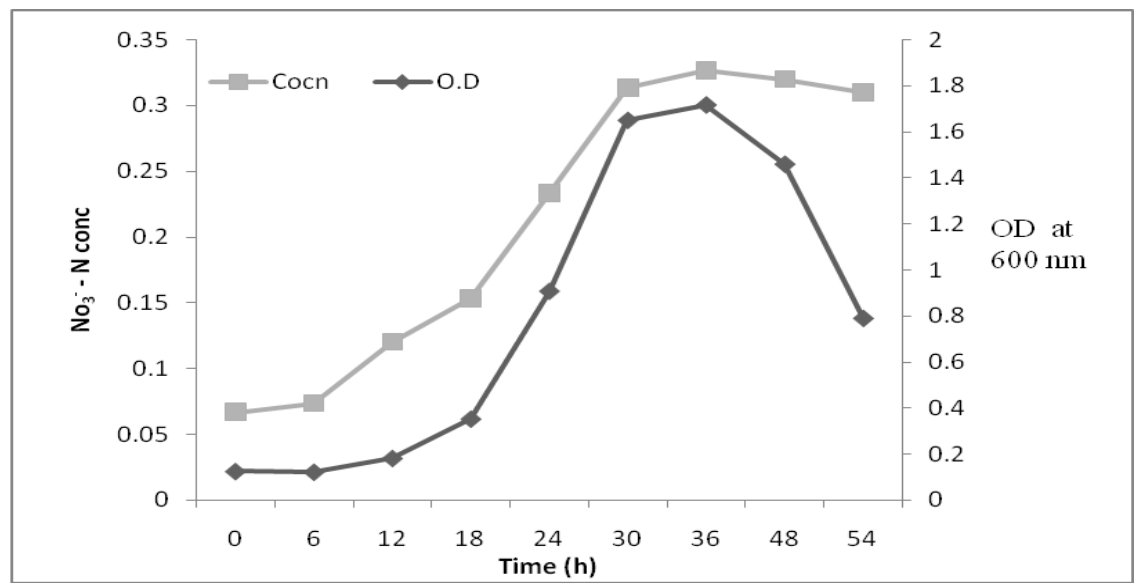

Fig.5 Cell growth and accumulation of Nitrate by ACM-1in MSM containing system at $30^{\circ} \mathrm{C}$ Symbols: diamonds, $\mathrm{No}_{3}{ }^{-}-\mathrm{N}$; Squares, cell growth at $\mathrm{OD}_{600}$

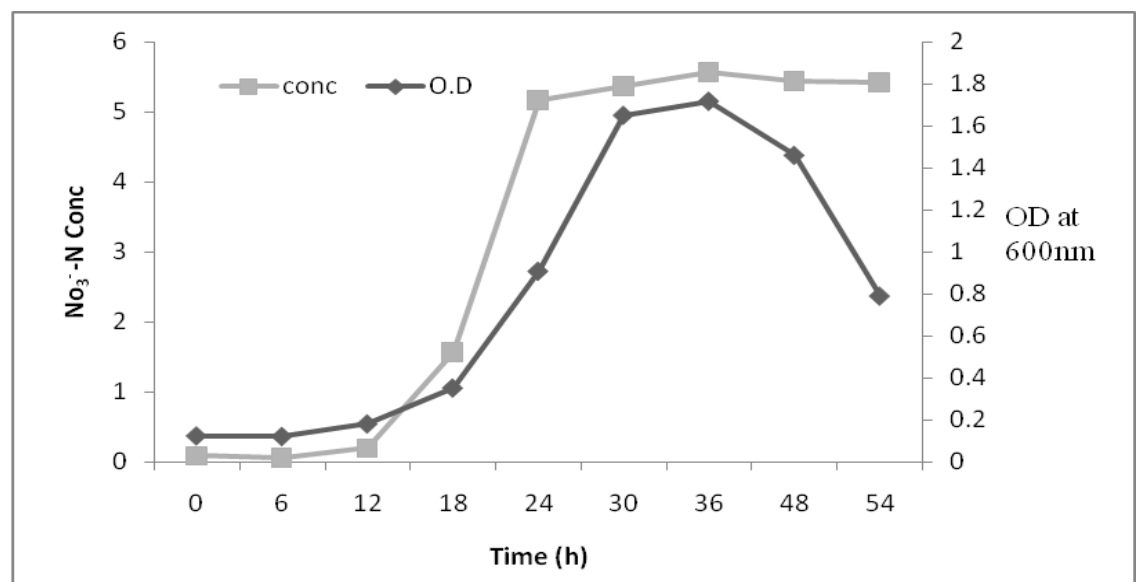


All the isolates didn't show acid production from lactose, maltose, mannitol, sucrose and low utization of glucose was observed. Twelve isolates showed positive for $16 \mathrm{~S}$ AOB gene amplification (465 bp) with CTO189F and CTO454R primers as represented in (Fig.1) and were presumed to be ammonia oxidizing bacteria. The 16S rDNA nucleotide sequence of strain ACM-1 was closely related (100\%) to Achromobacter xylosoxidans from NCBI gene bank data base. A phylogenetic tree was constructed based on closely related 16S rDNA sequences (Fig. 2). Morphological, biochemical and molecular analysis resembles that ACM-1 is Achromobacter xylosoxidans.

\section{Estimation of nitrification activity}

Isolates checked for the process of nitrification under different carbon sources at $30^{\circ} \mathrm{C}$. The specific growth rate of ACM- 1 on sodium pyruvate, trisodium acetate and sodium citrate was $0.35 \mathrm{~h}^{-1}, 0.27 \mathrm{~h}^{-1}$ and 0.22 $\mathrm{h}^{-1}$ whereas on glucose, moderate growth was recorded but ACM-1 didn't show any significant growth rate on sucrose, lactose. The growth at $\mathrm{O}_{600}$ and ammonia removal rate of ACM-1 at different temperatures in the MSM medium was studied under shaking condition. ACM-1 was capable to grow observed at $20^{\circ} \mathrm{C}, 25^{\circ} \mathrm{C}, 30^{\circ} \mathrm{C}, 37^{\circ} \mathrm{C}$. Cell growth and nitrifying efficiency of ACM-1 showed significant results at $30^{\circ} \mathrm{C}$ when compared to the $20^{\circ} \mathrm{C}, 25^{\circ} \mathrm{C}, 37^{\circ} \mathrm{C}$. Cell growth and nitrification activity of ACM-1 at $30^{\circ} \mathrm{C}$ during this study was elaborated. Initially, after $2 \mathrm{~h}$ of incubation when $1 \%$ sodium pyruvate was supplemented to the media, ACM-1 started growing, continued exponential phase for $30 \mathrm{hr}$ further reached to stationary phase by $36 \mathrm{hr}$ as $\mathrm{OD}_{600}$ increased froBBm 0.014 to 1.172 and then it started the decline phase after $36 \mathrm{~h}$. These results revealed that probable source of carbon to ACM-1 is sodium pyruvate and therefore the heterotrophic nature of the strain was confirmed. The specific growth rate of the strain at different temperatures ranged from 0.18-0.55 $\mathrm{h}^{-1}$. Robertson et al., (1995) reported the specific growth rate of Thiosphaera pantotropha about $0.28-0.45 \mathrm{~h}^{-1}$ under various growth conditions. The growth rates of A. faecalis No. 4 was reported to be $0.2 \mathrm{~h}^{-1}$ as reported (Joo et al., 2005) and $0.3 \mathrm{~h}$ ${ }^{1}$ was reported in Bacillus MS30 at initial ammonium concentration of about $70 \mathrm{ppm}$ (Mevel and Prieur, 2000). Based on the comparison between these heterotrophs, the growth rate of Achromobacter xylosoxidans is at high rate as well as high utilization of carbon. ACM-1 completely oxidized initial ammonium $\left(50 \mathrm{mg} \mathrm{L}^{-1}\right)$ within $36 \mathrm{~h}$ and the nitrification ratio for $\mathrm{NH}_{4}{ }^{+}-\mathrm{N} \mathrm{mg} \mathrm{L}{ }^{-1} \mathrm{~h}^{-1}$ with the ammonium removal rate was $1.38 \pm 0.44$ $\mathrm{NH}_{4}{ }^{+}-\mathrm{N} \mathrm{mg} \mathrm{L}{ }^{-1} \mathrm{~h}^{-1}$ as shown in Figure 3. Pseudomonas alcaligenes AS-1 showed the oxidation of $\mathrm{NH}_{4}^{+}-\mathrm{N}$ at the rate $1.15 \mathrm{mg} \mathrm{L}^{-1}$ $\mathrm{h}^{-1}$ (Su et al., 2006) where as the ammonium removal rate of Bacillus sp. LY reported at $0.43 \mathrm{mg} \mathrm{L}^{-1} \mathrm{~h}^{-1}$ (Zhao et al., (2010 a,b). Therefore, results appear to be Achromobacter xylosoxidans reported a high rate of ammonium removal when compared to Bacillus sp LY and Pseudomonas alcaligenes AS-1. Nitrification products $\left(\mathrm{No}_{2}^{-}{ }_{2}-\mathrm{N}\right.$ and $\mathrm{No}^{-}$ $3-\mathrm{N}$ ) were detected during the experimental period. There was slow increase in nitrite $\left(\mathrm{NO}_{2}{ }^{-} \mathrm{N}\right)$ concentration of about $5 \mathrm{ppm}$ till the isolate reached the log phase $(0-24 \mathrm{hr})$ and later it almost remained at constant rate during the experimental period (Fig. 4). Chen et al., (2006) reported that nitrite production by Rhodococcus spp was about 5.5-6 ppm during $10 \mathrm{~h}$ incubation which mostly resemble to the present study. The increase in the detection of nitrate concentration was observed during the $0-16 \mathrm{hr}$ of growth phase and there is no significant difference in the nitrate $\left(\mathrm{No}_{3}^{-}-\mathrm{N}\right)$ production during the stationary and decline phase (Fig. 5). Therefore, low levels of $\mathrm{No}_{2}^{-}-\mathrm{N}$ and $\mathrm{No}_{3}^{-}-\mathrm{N}$ accumulation was observed during the 
investigation period. The ammonium removal rate of A. xylosoxidans at different temperatures in the MSM medium was investigated during the study. At $25^{\circ} \mathrm{C}, 30^{\circ} \mathrm{C}$, $37^{\circ} \mathrm{C}$ the ammonia removal rates showed similar pattern of ammonia removal 0.90 , 1.33 and $1.19 \mathrm{NH}_{4}{ }^{+}-\mathrm{N} \mathrm{mg} \mathrm{L}{ }^{-1} h^{-1}$ except at $20^{0} \mathrm{C}$. It is observed that $\mathrm{NH}_{4}{ }^{+}-\mathrm{N}$ was reduced from $50 \mathrm{mg} \mathrm{L}^{-1}$ to $1.89 \pm 1.21 \mathrm{mg} \mathrm{L}^{-1}$ after 72 $\mathrm{h}$ of incubation with the nitrification ratio of $0.66 \mathrm{mg} \mathrm{L}^{-1} \mathrm{~h}^{-1} \mathrm{NH}_{4}{ }^{+}-\mathrm{N}$ at $20^{\circ} \mathrm{C}$.

There is no significant difference observed in the ammonia removal patterns during $30^{\circ} \mathrm{C}$ and $37^{\circ} \mathrm{C}$ incubation whereas ammonia removal rate at $20^{\circ} \mathrm{C}$ and $25^{\circ} \mathrm{C}$ was observed at lesser extent. The ammonia removal rate was recorded highest at $30^{\circ} \mathrm{C}$ in comparison to $25^{\circ} \mathrm{C}$ and $37^{\circ} \mathrm{C}$. Therefore, experimental results suggest that Achromobacter xylosoxidans is capable to oxidize $\mathrm{NH}_{4}{ }^{+}-\mathrm{N}$ and releases $\mathrm{No}_{2}^{-}-\mathrm{N}$ and $\mathrm{No}_{3}^{-}-\mathrm{N}$ during growth phase conditions.

In conclusion, Nitrifying bacteria plays a major role in conversion of ammonium to nitrite and helps in maintaining the water quality of the fresh water ponds. It is well known that fishes cultured in pond waters of greater than $1.5 \mathrm{mg} / \mathrm{N}$ is toxic to fishes. However the toxicity varies between the species of the fishes reared and size of the animals affected. In freshwater aquaculture system, the acceptable level of unionized ammonia is $0.0025 \mathrm{ppm}$ (Chen et al., 2006). Probably, aerating the pond water can reduce the ammonia levels but the nitrifying bacteria will definitely oxidize the toxic unionized ammonium to non-toxic nitrate. Therefore, the results of the present study indicate that Achromobacter xylosoxidans might be a preferred as nitrifying bacteria to oxidize ammonium as well as to reduce nitrite in fish ponds.

\section{Acknowledgement}

First author is thankful to Director, Central
Institute of Fisheries Technology, Cochin \& Central Institute of Fisheries Education, Mumbai for providing facilities and support to conduct the present work.

\section{References}

Arillo A, Margiocco C, Melodia F, Mensi, P and Schenone G, Biochemical aspects of water quality criteria: the case of ammonia pollution. Envir. Technol. Lett, 1981, 2, 285-292.

Bollmann A, French E, Laanbroek HJ, Isolation, cultivation, and characterization of ammonia-oxidizing bacteria and archaea adapted to low ammonium concentrations. Meth Enzymol 2011, 486, 55-88. doi:10.1016/B978-0-12-3812940.00003-1.

Boyd CE, Wood CW, Thunjai T, Rowan M and Dube K. Pond soil characteristics and dynamics of soil organic matter and nutrients. Eighteenth Annual Technical Report. Pond Dynamics/Aquaculture CRSP, Oregon State University, Corvallis, Oregon, 2001, 1-12.

Boyd CE, Ammonia toxicity degrades animal health, growth. Global Aquaculture Advocate, 2013 40-43.

Brune DD, Schwartz G, Eversole AG, Collier JA, and Schwedler TE, (Intensification of pond aquaculture and high rate photosynthetic systems. Aquacultural engineering, 2003, 28, 65-86.

Camargo JA, Alonso A, Ecological and toxicological effects of inorganic nitrogen pollution in aquatic ecosystems: A global assessment. Environ Int, 2006, 32,831-49.

Chain P, Lamerdin J, Larimer F, Regala, W, Lao V, Land M, Hauser L, Hooper A, Klotz M, Soto L S, Arciero D, Hommes $\mathrm{N}$, Whittaker M, Arp D, Complete genome sequence of the ammonia oxidizing bacterium and obligate 
chemolithoautotroph Nitrosomonas europaea. Journal of Bacteriology, 2003, 185, 2759-2773. http://doi.org/10.1128/JB.185.9.27592773.2003.

Chen P, Li J, Li QX, Wang Y, Li S, Ren T, Wang L, Simultaneous heterotrophic nitrification and aerobic denitrification by bacterium Rhodococcus sp CPZ24. Bioresource technology, 2012,116, 26670. 10.1016/j.biortech.2012.02.050.

Chen P, Qing X Li, Wang Y, Li S, Ren T, Wang L Simultaneous heterotrophic nitrification and aerobic denitrification by bacterium Rhodococcus sp CPZ24. Bioresource technology, 2012,116. 26670. 10.1016/j.biortech.2012.02.050.

Chen S, Ling J, Blancheton JP, Nitrification kinetics of biofilm as affected by water quality factors. Aquacultural Engineering, 2006, 34, 179-197.

FAO 2016. The State of World Fisheries and Aquaculture 2016. Contributing to food security and nutrition for all.

Folke C and Kautsky N. The role of ecosystems for sustainable development of aquaculture. Ambio, 1989,4,18.

Garrity GM, Bell JA and Lilburn TG, Taxonomic Outline of the Prokaryotes. Bergey's Manual of Systematic Bacteriology, 2004, 2nd edn. Springer. http://dx.doi.org/10.1007/bergeys outline.

Hargreaves JA, Nitrogen biogeochemistry of aquaculture ponds. Aquaculture, 1998, $166,181-212$.

Haywood GP, Ammonia toxicity in teleost fish: a review. Canadian Technical Report of Fisheries and Aquatic Sciences, 1983, 1177, 1-35.

Joo HS, Hirai, M, Shoda M, Characteristics of ammonium removal by heterotrophic nitrification-aerobic denitrification by Alcaligenes faecalis No. 4. J. Biosci. Bioeng. 2005,100, 184-191.

Kandeler E and Gerber H, Short-Term Assay of Soil urease Activity Using Colorimetric Determination of Ammonium. Biol Fert Soils, 1988, 6, 68-72.

Keeney DR and Nelson DW, Nitrogen inorganic forms. In: Page AL. Methods of Soil analysis - part 2. American Society of Agronomy, Madison, WI, USA, 1982, 643-698.

Korner S, Das SK, Veenstra S, and Vermaat $\mathrm{JE}$, The effect of $\mathrm{pH}$ variation at the ammonium/ammonia equilibrium in wastewater and its toxicity to Lemna gibba. Aquatic botany, 2001,71, 71-78.

Kowalchuk GA, Stephen JR, de Boer W, Prosser, JI, Embley TM and Woldendorp JW. Analysis of ammoniaoxidizing bacteria of the $\beta$-subdivision of the class Proteobacteria in coastal sand dunes by denaturing gradient gel electrophoresis and sequencing of PCRamplified 16S ribosomal DNA fragments. Applied and Environmental Microbiology 1997, 63, 1489- 1497.

Lang T, Peters G, Hoffmann R, Meyer E, Experimental investigations on the toxicity of ammonia: Effects on ventilation frequency, growth, epidermal mucous cells, and gill structure of rainbow trout Salmo gairdneri. Dis. Aquat. Org, 1987,3, 159-165.

Mevel G, Prieur D, Heterotrophic nitrification by a thermophilic Bacillus species as influenced by different culture conditions. Can. J. Microbiol, 2000, 46, 465-473.

Prosser J, Autotrophic Nitrification in Bacteria. Advances in microbial physiology, 1989, 30, 125-81. 10.1016/S0065-2911(08) 60112-5.

Robertson LA, Niel EWJ, Torremans RAM and Kuenen, JG. Simultaneous nitrification and denitrification in Aerobic chemostat Cultures of Thiosphaera pantotropha. Applied and 
Environmental Microbiology, 1988, 54, 2812-2818.

Russo RC, Ammonia, nitrite, and nitrate, In: Fundamentals of aquatic toxicology and chemistry. Rand, G.M. and S.R. Petrocelli (Eds.). Hemisphere Publishing Corp., Washington, D.C. 1985, 455-471.

Shand CA, Williams BL, Coutts G, Determination of $\mathrm{N}$-species in soil extracts using microplate techniques. Talanta 2008, 74: 648-654. doi:10.1016/j.talanta.2007.06.039.

Shilo $\mathrm{M}$ and Rimon A, Factors which affect the intensification of fish breeding in Israel. Ammonia transformation in intensive fish ponds. Bamidgeh, 1982, 34,101- 114.

Su JJ, Yeh KS, Tseng PW, A Strain of Pseudomonas sp. isolated from piggery wastewater treatment systems with heterotrophic nitrification capability in Taiwan. Curr. Microbiol, 2006, 53, 7781.

Tomasso JR, Goudie CA, Simco BA, Davis $\mathrm{KB}$, Effects of environmental $\mathrm{pH}$ and calcium on ammonia toxicity in channel catfish. Am. Fish Soc, 1980, 109: 229234.

Turner SW, Pryer KM, Miao,VPW, Palmer JD. Investigating deep phylogenetic relationships among cyanobacteria and plastids by small subunit rDNA sequence analysis. Journal of Eukaryotic Microbiology, 1999, 46. 327 - 338 $10.1111 / \mathrm{j} .1550-$

7408.1999.tb04612.

Verhagen FJM and Laanbroek HJ,
Competition for ammonium between nitrifying and heterotrophic bacteria in dual energy limited chemostats. Appl. Environ. Microbiol. 1991, 57, 32553263.

Walkley A and Black IA, Soil Sc., 1934, 37, 29.

Watson SW, Taxonomic considerations of the family Nitrobacteracaea Buchanan: Requests for the opinions. Int.J.Syst. Bacteriol. 1971, 21: 254-270.

Wright PA, Nitrogen metabolism and excretion. Comparative Biochemistry and Physiology, 2007. 148, 46-49.

Zhang J, Pengxia W, Hao B and Ziniu Y, Heterotrophic nitrification and aerobic denitrification by the bacterium Pseudomonas stutzeri YZN-001. Bioresource technology, 2011, 102, 9866-9. 10.1016/j.biortech.2011.07.118.

Zhang, QL, Liu Y, Ai GM, Miao LL, Zheng HY, Liu ZP, The characteristics of a novel heterotrophic nitrification-aerobic denitrification bacterium, Bacillus methylotrophicus strain L7. Bioresour. Technol, 2012, doi:10.1016/j.biortech. 2011.12.139.

Zhao B, He YL, Hughes J, Zhang XF, Heterotrophic nitrogen removal by a newly isolated Acinetobacter calcoaceticus HNR. Bioresour. Technol. 2010b, 101, 5194-5200.

Zhao B, He YL, Zhang, XF, Nitrogen removal capability through simultaneous heterotrophic nitrification and aerobic denitrification by Bacillus spp. LY. Environ. Technol. 2010a, 31, 409-416.

\section{How to cite this article:}

Ahamed Basha, K., Toms C. Joseph, K.V. Lalitha, D. Vineetha1, G. Rathore, Gayatri Tripati and Pani Prasad, K. 2018. Nitrification Potential of Achromobacter xylosoxidans Isolated from Fresh Water Finfish Farms of Kerala, India. Int.J.Curr.Microbiol.App.Sci. 7(08): 2645-2654. doi: https://doi.org/10.20546/ijcmas.2018.708.273 